\title{
Characterization of swine stress gene by DNA testing using plucked hair as a source of DNA
}

\author{
Reginaldo Gaspar Bastos ${ }^{1}$, Joreci Federizzi ${ }^{1}$, João Carlos Deschamps ${ }^{1}$, Ricardo Cardellino ${ }^{2}$ and Odir Antônio Dellagostin ${ }^{1}$
}

\begin{abstract}
The swine stress gene ( $\mathrm{hal}$ ) in recessive homozygotes ( $n$ n) leads to porcine stress syndrome (PSS), and is associated with pale, soft, exudative pork (PSE). In heterozygosis $(N n)$ it is linked to poor carcass quality. A total of 179 pigs (86 Large White, 69 Landrace, 12 Duroc and 12 Pietrain) were characterized as normal homozygotes $(N N)$, heterozygotes or recessive homozygotes following amplification of a target region of the hal gene using the polymerase chain reaction (PCR), followed by a restriction endonuclease assay. Plucked hair was used as a source of genomic DNA. The resulting PCR was digested with the restriction enzyme $C f o I$, followed by agarose gel electrophoresis. Of 179 animals tested, $70 \%$ were $N N, 28 \%$ were $N n$, and $2 \%$ were $n n$. The frequency of heterozygotes was higher (P $<0.05$ ) in Landrace ( 0.43 for $N n$ ) than in Large White pigs ( 0.09 for $N n$ ). Nine of the 12 Pietrain animals were $N n$ and three were $n n$, suggesting a high frequency for the $n$ allele in this breed. These results may be related to the incidence of PSS and PSE in these two breeds, both of which are widely used in breeding programs. The utilization of plucked hair as the source of genomic DNA was a noninvasive and quick method to screen farm animals.
\end{abstract}

\section{INTRODUCTION}

The swine stress gene $(\mathrm{hal})$ is located on chromosome 6 (p1.1-q2.1) and codes for ryanodine receptors, which are $\mathrm{Ca}^{2+}$ release channels of skeletal muscle sarcoplasmic reticulum (Otsu et al., 1991). Porcine stress syndrome (PSS) is an inherited myopathology in which skeletal muscle contraction, hypermetabolism and an elevation in body temperature are triggered by inhaled anesthetics and environmental stress (Louis et al., 1990; Santoro and Faucitano, 1996). Comparison of sequence of full-length hal cDNA (Genbank M91451) from PSS susceptible and PSS non-susceptible pigs has revealed 18 single nucleotide polymorphisms between these two types of pigs. One of the polymorphisms involves the substitution of cytosine (PSS non-susceptible) by a thymine (PSS susceptible) at nucleotide 1843. This alteration results in the replacement of an arginine at position 615 by a cysteine (Fujii et al., 1991). As a consequence, in recessive homozygotes $(n n)$ the gene hal leads to PSS and the major post-mortem manifestation of pale, soft and exudative pork (PSE). In heterozygosis ( $\mathrm{Nn}$ ) the hal gene produces lower carcass quality (Prommier and Houde, 1993; Cheak et al., 1994; Webb, 1996), but possibly higher carcass weight (Zhang et al., 1992; Leach et al., 1996; Fávero, 1997). The polymorphism at nucleotide 1843 of the hal gene has recently been characterized by a DNA test using blood or a muscle biopsy as the source of genomic DNA (Houde et al., 1993; Cheak et al., 1994).

In this study, we assessed the validity of the DNA test in commercial pigs using PCR amplification of the target region of hal gene followed by a restriction endonuclease assay (REA). We also examined the feasibility of using plucked hair as source of genomic DNA, and determined the frequency of each hal genotype in Landrace, Large White, Duroc and Pietrain pig breeds.

\section{MATERIAL AND METHODS}

\section{Animals}

One hundred seventy-nine pigs (86 Large White, 69 Landrace, 12 Duroc and 12 Pietrain) were studied. All animals came from a single commercial farm in the State of Rio Grande do Sul, Brazil. Plucked hair was collected from randomly chosen pigs.

\section{Extraction of genomic DNA}

Genomic DNA was extracted from the hair roots using two protocols. In protocol I (Bauerová et al., 1995), 10 hair roots were suspended in $100 \mu \mathrm{l}$ of lysis buffer $(10 \mathrm{mM}$ Tris- $\mathrm{HCl}, \mathrm{pH}$ 8.0, $10 \mathrm{mM}$ EDTA, $100 \mathrm{mM} \mathrm{NaCl}, 2 \%$ SDS, $70 \mathrm{mM} \mathrm{DTT}$ and $0.4 \mathrm{mg} / \mathrm{ml}$ of proteinase $\mathrm{K}$ ), and then incubated at $45^{\circ} \mathrm{C}$ overnight. Five microliters was used in the PCR reaction. In protocol II, modified from Drissing et al. (1996), 1-3 hair roots were incubated at room temperature for $5 \mathrm{~min}$ in $0.5 \mu \mathrm{l}$ of $0.1 \mathrm{M} \mathrm{NaOH}$, after which $4.5 \mu \mathrm{l}$ of $0.02 \mathrm{M}$ Tris-HCl, $\mathrm{pH} 7.4$, was added. The PCR reaction mixture $(20 \mu \mathrm{l})$ was then added to the tube containing the above extract. As alternative sources of DNA, blood and semen samples were also used and the DNA was extracted according to the method described by Sambrook et al. (1989). 


\section{PCR and REA}

The PCR reactions were done in a final volume of 25 $\mu \mathrm{l}$ containing $200 \mu \mathrm{M}$ of each dNTP, $2.5 \mu \mathrm{l}$ of PCR buffer with a final concentration of $1.5 \mathrm{mM} \mathrm{MgCl}, 0.2 \mu \mathrm{M}$ of each primer (forward 5' -GTTCCCTGTGTGGCAATGGTG3' and reverse 5'-ATCTCTAGAGCCAGGGAGCAAGTTCT CAGTAAT-3') (Fujii et al., 1991), 1 U of Taq DNA polymerase (CENBIOT/RS, UFRGS) and $5 \mu$ l of extraction solution containing genomic DNA (Innis et al., 1990). The PCR reaction was carried out in a Perkin Elmer 2400 thermocycler with the following settings: $1 \mathrm{~min}$ at $95^{\circ} \mathrm{C}, 1$ min at $56^{\circ} \mathrm{C}$, and $1 \mathrm{~min}$ at $72^{\circ} \mathrm{C}$ for 30 cycles with a final cycle of $7 \mathrm{~min}$ at $72^{\circ} \mathrm{C}$. Five microliters of the PCR product was digested with $5 \mathrm{U}$ of $C f o \mathrm{I}$ (Boehringer Mannhein) for $3 \mathrm{~h}$ at $37^{\circ} \mathrm{C}$. Digestion by $C f o I$ produced two DNA fragments of $49 \mathrm{pb}$ and $32 \mathrm{pb}$ for the $N$ allele and an intact $81 \mathrm{pb}$ for the " $n$ " allele. The digested product was submitted to electrophoresis on a $4 \%$ agarose gel containing $0.5 \mu \mathrm{g}$ of ethidium bromide/ml (Sambrook et al., 1989), visualized with an UV transilluminator and photographed using a Kodak DC40 digital camera.

\section{Gene frequency}

The genotype frequencies of the hal gene $(\mathrm{NN}, \mathrm{Nn}$, and $n n)$ among the breeds were analyzed using the chi-square test $\left(\chi^{2}\right)$.

\section{RESULTS AND DISCUSSION}

PCR amplified a specific 81-base pair (bp) DNA fragment from the hal gene using different sources of pig DNA. Collection and transportation of plucked hair were quite easy so this was the source used throughout this study. Protocol II for DNA extraction from plucked hair gave the most consistent results, and since it was simpler and easier to perform than protocol I, this method was adopted as standard. A single hair root was enough to allow amplification of the expected DNA fragment (Figure 1). The impurities present in the DNA samples apparently did not affect amplification of the target DNA. The size of the fragment amplified by PCR was the same, $81 \mathrm{bp}$, in all samples analyzed.

Digestion of the PCR product with $C f o$ I produced two fragments of $49 \mathrm{bp}$ and $32 \mathrm{bp}$ for normal homozygotes $(N N)$, three fragments of $81 \mathrm{bp}, 49 \mathrm{bp}$ and $32 \mathrm{bp}$ for heterozygotes $(\mathrm{Nn})$ and an undigested fragment of $81 \mathrm{bp}$ for recessive homozygotes $(n n)$ (Figure 2).

The gene frequency of the $n$ allele of the hal gene was higher $(\mathrm{P}<0.05)$ in Landrace than in Large White animals (Table I). The frequency of heterozygotes was higher $(\mathrm{P}<0.05)$ in Landrace pigs than Large White pigs.

Comparisons between Duroc and Pietrain pigs were not done, because of the small sample size. However, there was a tendency towards a high frequency of the $n$ allele in

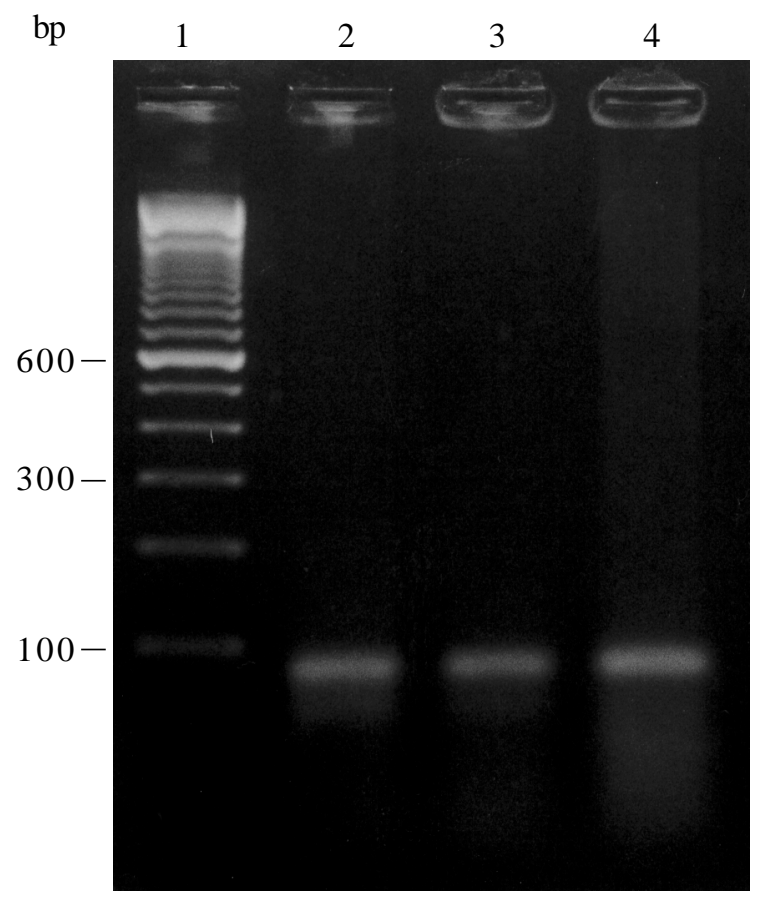

Figure 1 - PCR products obtained using DNA extracted with protocol II. Lane 1: 100-bp ladder molecular weight marker (Gibco BRL); lane 2: DNA extracted from a single hair root; lane 3, DNA extracted from two hair roots, and lane 4: DNA extracted from three hair roots.

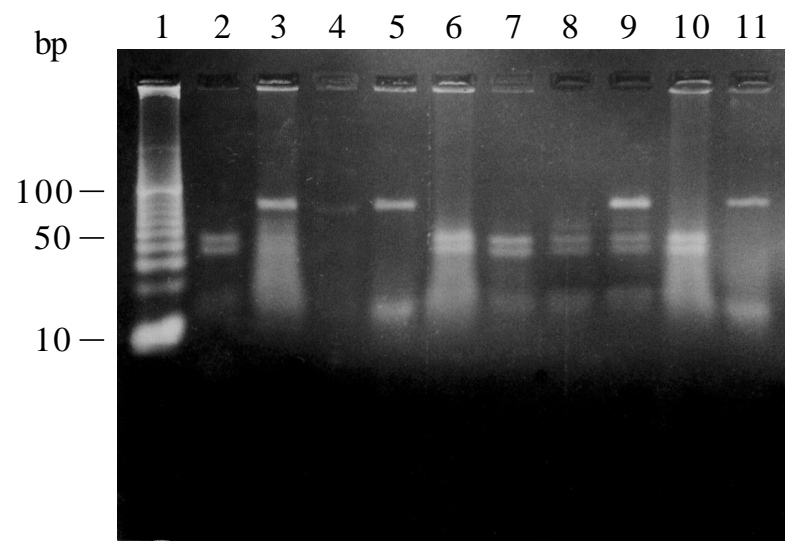

Figure 2 - Electrophoretic profile of PCR products digested with $C f o I$. Lane 1: 10-bp ladder molecular weight marker (GIBCO BRL); lanes 2, 6, 7, 8, and 10: normal homozygotes $(N N)$ (two Large White pigs, two Landrace pigs, and one Duroc pig); lanes 3, 4, and 9: heterozygotes ( $\mathrm{Nn}$ ) (two Landrace pigs and one Pietrain pig); lanes 5 and 11: recessive homozygotes ( $n n)$ (two Pietrain pigs).

Pietrain pigs and a low frequency of this allele in Duroc pigs. No Pietrain animal was characterized as $N N$.

Plucked hair was a suitable source of DNA for PCR, and it was easily collected and transported from the farm to the laboratory. This source of DNA should facilitate the characterization of the hal genotype in farm animals. Collection and use of blood or semen as a source of DNA is 
Table I - Frequencies of the hal gene in different breeds of pigs.

\begin{tabular}{|lcllc|}
\hline \multirow{2}{*}{ Breeds } & \multirow{2}{*}{ No. } & \multicolumn{3}{c|}{ Gene frequency (\%) } \\
\cline { 3 - 5 } & & $N N($ No.) & $N n$ (No.) & $n n$ (No.) \\
\hline Large White & 69 & $0.91^{\mathrm{a}}(78)$ & $0.09^{\mathrm{a}}(8)$ & - \\
Landrace & 86 & $0.56^{\mathrm{b}}(38)$ & $0.43^{\mathrm{b}}(31)$ & - \\
Duroc & 12 & $0.83(10)$ & $0.16(2)$ & - \\
Pietrain & 12 & - & $0.75(9)$ & $0.25(3)$ \\
Total & 179 & $0.70(126)$ & $0.28(50)$ & $0.02(3)$ \\
\hline
\end{tabular}

$N N$ - Normal homozygotes; $N n$ - heterozygotes; $n n$ - recessive homozygotes; ${ }^{\text {a,b }}$ Different letter means $\mathrm{P}<0.05$.

laborious and, in some cases, dangerous because of the stress caused to the animal during sample collection. Death may occur if the genotype for the hal gene is $n n$.

The high frequency of heterozygotes $(\mathrm{Nn})$ in Landrace pigs and the high frequency of heterozygotes $(\mathrm{Nn})$ and recessive homozygotes $(n n)$ in Pietrain pigs may be related to the incidence of PSS and PSE, since both of these breeds are used widely in breeding programs and commercial farms. A study to correlate the presence of the $n$ allele with carcass traits in these animals was done by Bastos et al. (2000), and no correlation was found between the presence of the $n$ allele and higher carcass weight, contrary to findings of Zhang et al. (1992), Leach et al. (1996) and Fávero (1997).

As the presence of the hal gene, both in heterozygosity and recessive homozygosity, does not seem to be associated with better carcass weight, and the utilization of these animals may lead to lower carcass quality, breeding programs should aim at eliminating this genotype from the herd. The use of hair roots as a source of DNA should facilitate the analysis of the genotype of hal gene of different breeds and crossbreed pigs.

\section{ACKNOWLEDGMENTS}

We thank Dr. L.S. Ozaki for suggesting the protocols for the extraction of genomic DNA. This work was supported by FAPERGS (Project No. 9802179).

\section{RESUMO}

O gene do estresse suíno ( $h a l$ ) em homozigose recessiva (nn) ocasiona a síndrome do estresse porcino (PSS), e está relacionado com a ocorrência da carne pálida, mole e exudativa (PSE). Em heterozigose $(\mathrm{Nn})$ está associado com diminuição da qualidade de carcaça. Um total de 179 suínos (86 Large White, 69 Landrace, 12 Duroc e 12 Pietrain) foram caracterizados como homozigotos normais $(N N)$, heterozigotos e homozigotos recessivos por análise do DNA usando a reação de polimerização em cadeia (PCR), seguida de um ensaio com endonuclease de restrição. Foi utilizado folículo piloso como fonte de DNA genômico. O produto do PCR foi digerido com a enzima de restrição $C f o \mathrm{I}$, seguindo-se análise dos fragmentos por eletroforese em gel de agarose. Dentre os 179 animais analisados, $126(70,0 \%)$ foram caracterizados como $N N$, $50(28,0 \%)$ como $N n$, e $3(2,0 \%)$ caracterizados como $n n$. A frequiência de heterozigotos foi maior $(\mathrm{P}<0,05)$ em animais da raça Landrace do que em animais da raça Large White. Nove animais da raça Pietrain foram classificados como heterozigotos e tres como homozigotos recessivos. Estes resultados podem estar relacionados com a incidência de PSS e PSE nestas raças, as quais são largamente utilizadas em programas de cruzamento. A utilização de folículo piloso como fonte de DNA genômico foi um método rápido e não-invasivo que viabiliza a execução da caracterização do gene $h a l$.

\section{REFERENCES}

Bastos, R.G., Federizzi, J., Deschamps, J.C., Cardellino, R. and Dellagostin, O.A. (2000). Efeito do gene do estresse sobre características de carcaça de suínos comerciais. Rev. Bras. Zootec. (in press).

Bauerová, M., Vasicek, D., Uhrin, P., Chrenek, P., Mlynek, J. and Bulla, J. (1996). Detection of malignant hyperthermia in pigs by DNA-test using plucked hair as a source of DNA. Pig News Inf. 16: 109N-111N.

Cheak, K.S., Cheak, A.M. and Krausgrill, D.I. (1994). Identification of variations in meat quality in live pigs free of the halothane gene using biopsy samples of M. longissimus dorsi. Pig News Inf. 15: 55-57.

Drissing, J., Rudbeck, L. and Marcher, H. (1996). A five minute procedure for extraction of genome DNA from whole blood, semen and forensic stain for PCR. In: Advances in Forensic Haemogenetics (Carracedo, A., ed.). Springer-Verlag, New York, pp. 269-271.

Fávero, J.A. (1997). Influência do gene halotano sobre o desempenho produtivo de suínos. In: Anais do VIII Congresso Nacional da Associação Brasileira de Veterinários Especialistas em Suínos, ABRAVES, Foz-do-Iguaçu, PR, Brasil, 1997, pp. 395-396.

Fujii, J., Otsu, K., Zorzato, F., Leon, S., Khanna, V., Weiler, J.E., O'Brien, P.J. and MacLennan, D.H. (1991). Identification of a mutation in porcine ryanodine receptor associated with malignant hyperthermia. Science 253: 448-451.

Houde, A., Pommier, S.A. and Roy, R. (1993). Detection of the ryanodine receptor mutation associated with malignant hyperthermia in purebred swine populations. J. Anim. Sci. 71: 1414-1418.

Innis, M.A., Gelfand, D.H., Sninky, J.J. and White, T.J. (1990). PCR Protocols: A Guide to Methods and Applications. Academic Press, San Diego.

Leach, L.M., Ellis, M., Sutton, D.S., McKeith, F.K. and Wilson, E.R. (1996). The growth performance, carcass characteristics, and meat quality of halothane carrier and negative pigs. J. Anim. Sci. 74: 934-943.

Louis, C.F., Gallant, E.M., Remple, E. and Mickelson, J.R. (1990). Malignant hyperthermia and porcine stress syndrome: a tale of two species. Pig News Inf. 11: 341-344.

Otsu, K., Khanna, V.K. and Archibald, A.L. (1991). Cosegregation of porcine malignant hyperthermia and a probable causal mutation in the skeletal muscle ryanodine receptor gene in backcross families. Genomics 11: 744-750.

Prommier, S.A. and Houde, A. (1993). Effect of the genotype malignant hyperthermia as determined by a restriction endonuclease assay on the quality characteristics of commercial pork loins. J. Anim. Sci. 71: 420-425.

Sambrook, J., Fritsch, E.F. and Maniatis, T. (1989). Molecular Cloning: A Laboratory Manual. 2ndedn. Cold Spring Harbor Laboratory, New York.

Santoro, P. and Faucitano, L. (1996). Stress in pig production. Pig News Inf. $17: 49 \mathrm{~N}-52 \mathrm{~N}$

Webb, A.J. (1996). Future challenges in pig genetics. Pig News Inf. 17: 11N$16 \mathrm{~N}$.

Zhang, W., Kuhlers, D.L. and Rempel, W.E. (1992). Halothane gene and swine performance. J. Anim. Sci. 70: 1307-1313.

(Received February 17, 1999) 
